Original Article

Artigo Original

Sandro Júnior Henrique Lima ${ }^{1}$

Leandro de Araújo Pernambuco²

Aline de Lima Lins ${ }^{3}$

Lucas Carvalho Aragão Albuquerque ${ }^{1}$

Hilton Justino da Silva ${ }^{4}$

Keywords

Rhinitis

Mouth Breathing

Stomatognathic System

Speech

Jaw

Descritores

Rinite

Respiração Bucal

Sistema Estomatognático

Fala

Mandíbula

Correspondence address:

Sandro Júnior Henrique Lima

Rua Professor Artur de Sá, s/n. Cidade

Universitária,Recife (PE), Brasil,

CEP: 50740-520.

E-mail: sandrofono@hotmail.com

Received: 08/18/2014

Accepted: 03/01/2015

\section{Jaw movement during the speech \\ in children with allergic rhinitis}

\author{
Movimentos mandibulares na fala \\ em crianças com rinite alérgica
}

\begin{abstract}
Introduction: Allergic rhinitis can cause changes in stomatognathic functions, which may alter the mandibular dynamics. Electrognathography is used in the recording of jaw movements, making it valid for analysis of movements in speech. Purpose: To characterize the amplitude and velocity of jaw movements during speech in children with and without allergic rhinitis. Methods: The sample consisted of 32 children aged 7-12 years, treated at a university hospital, divided into two groups: one with rhinitis and the other without rhinitis. To capture the jaw movements during speech, we used an electrognathography with the aid of a list of phonetically balanced figures. For the analysis of data, we used, in addition to descriptive statistics, nonparametric tests, Spearman correlation coefficient and the Mann-Whitney test, with a significant value of $\mathrm{p}=0.05$. Results: No significant difference was observed in jaw movements between groups, with values of $\mathrm{p}$ equals to $0.175,0.650$, and 0.462 for amplitude and jaw opening and closing velocity, respectively. However, a strong correlation was observed between the variables velocity and amplitude of mouth opening, being slightly higher in the group of children with allergic rhinitis. Conclusion: The amplitude and velocity of jaw movements are found to be similar in children with and without allergic rhinitis, and a correlation exits between these variables. In addition, they were more heterogeneous in the group without allergic rhinitis.
\end{abstract}

\section{RESUMO}

Introdução: A rinite alérgica pode causar alterações nas funções estomatognáticas; tais modificações podem alterar a dinâmica mandibular. A eletrognatografia é utilizada no registro dos movimentos de mandíbula, o que a torna válida para análise desses movimentos na fala. Objetivo: Caracterizar a amplitude e a velocidade dos movimentos de mandíbula durante a fala em crianças com e sem rinite alérgica. Métodos: A amostra foi composta por 32 crianças com idade entre 7 e 12 anos, atendidas em um hospital universitário, divididas em dois grupos, um de riníticos e outro de não riníticos. Para captação dos movimentos mandibulares durante a fala, foi utilizado um eletrognatógrafo com o auxílio de uma lista de figuras foneticamente balanceadas. Na análise dos dados utilizaram-se, além da estatística descritiva, os testes não paramétricos, coeficiente de correlação de Spearman e o teste de Mann-Whitney, considerando significativo o valor de $\mathrm{p}=0,05$. Resultados: Não se observou diferença significativa nos movimentos mandibulares entre os grupos, com valores de p iguais a $0,175,0,650$ e 0,462 , para a amplitude e as velocidades de abertura e o fechamento mandibular, respectivamente. No entanto, houve correlação forte entre as variáveis velocidade e amplitude de abertura da boca, sendo discretamente maior no grupo de crianças com rinite alérgica. Conclusão: Observou-se que a amplitude e a velocidade dos movimentos mandibulares são semelhantes em crianças com e sem rinite alérgica, e que existe correlação entre estas variáveis; além disso, seus valores apresentaram-se de forma mais heterogênea nos não riníticos.

Study carried out at Hospital das Clínicas da Universidade Federal de Pernambuco - UFPE - Recife (PE), Brasil (1) Graduate Program in Neuropsychiatry and Behavioral Sciences, Universidade Federal de Pernambuco UFPE - Recife (PE), Brasil.

(2) Graduate Program in Collective Health, Universidade Federal do Rio Grande do Norte; Department of Speech Language Pathology and Audiology, Universidade Federal do Rio Grande do Norte - UFRN - Recife (PE), Brasil.

(3) Speech Language Pathology and Audiology course, Universidade Federal de Pernambuco - UFPE - Recife (PE), Brasil.

(4) Graduate Program in Nutrition, Universidade Federal de Pernambuco; Department of Speech Language Pathology and Audiology, Universidade Federal de Pernambuco - UFPE - Recife (PE), Brasil.

Conflict of interests: nothing to declare. 


\section{INTRODUCTION}

Allergic rhinitis is defined as an inflammatory response of the nasal mucosa to exposure to allergen factors mediated by immunoglobulin $\mathrm{E}$, which may result in chronic or recurrent symptoms $\mathrm{s}^{(1)}$. The consequences of this clinical entity are changes on quality of life and reduction in academic and professional performance, causing economic repercussions ${ }^{(2)}$.

It is noted in scientific literature that patients with allergic rhinitis have modifications in the functions of chewing, swallowing, and breathing ${ }^{(3)}$ - the latter being mainly related to nasal obstruction, which is the predominant symptom in this pathology and directly relates to changes in the stomatognathic system $^{(4-6)}$.

Some authors say that with the appearance of nasal obstruction and possibly opening of the mouth to breathe, there are structural alterations that cause imbalance in orofacial functions ${ }^{(7)}$. These changes appear by a neuromuscular response that induces the adjustment of various structures of the stomatognathic system, generating physiologically inappropriate muscular activity. Therefore, skeletal, dental, and muscle changes are caused, while hypotrophy, hypotonia, and hypofunction of the mandibular elevator muscles may occur ${ }^{(8,9)}$.

It is also noted that the production of speech depends on the mobility of the phonoarticulatory system, such as tongue, lips, and cheeks, as well as the positioning of teeth, tongue, and jaws ${ }^{(10)}$. Problems in this function are associated with the occurrence of alterations in mobility, tone, and posture of the phonoarticulatory system and orofacial disorders ${ }^{(11)}$. Therefore, jaw movements may be modified during speech production in the occurrence of nasal obstruction.

A method that records the mandibular dynamics is electrognathography, which works through a computerized system of three-dimensional analysis of jaw movements. In addition to simplifying the recording of jaw movements, electrognathography is a test that may help in diagnosis, monitoring, and development of stomatognathic alterations ${ }^{(12)}$. In the evaluation of the jaw movements during speech through electrognathography, the so-called structured situations may be used, which allow the nonoccurrence of pauses and minimize alterations in velocity, better showing the performance of motor mechanisms of speech production ${ }^{(13)}$. Examples of such situations are repetition of phonemes or even repetition of words.

Thus, the objective of this study was to characterize the amplitude and velocity of jaw movements during the speech of children with and without allergic rhinitis.

\section{METHODS}

This study was observational, descriptive, and transversal. The nonprobabilistic sample comprised 32 children, 18 female and 14 male, aged 7-12 years, treated at the Clinics of Allergy, Immunology and Pediatrics at a university hospital, between April and June 2013. The selection of participants was through a convenience criteria related to the demand for care in the clinics.

Participants were divided into groups consisting of 16 children with a medical diagnosis of allergic rhinitis (8 females) and a control group with the same number of volunteers, consisting of children without allergic rhinitis (10 females).

The children were selected through the consultation of medical records of the clinics mentioned, considering the criteria for inclusion and exclusion of this study.

Children aged 7-12 years and having been diagnosed with allergic rhinitis were included in the study group. The control group had children without rhinitis, aged 7-12 years.

Children presenting craniofacial malformations; using braces; lacking dental elements that could compromise speech; presenting neurological syndromes; and presenting any communicative, neurological, cognitive, and sensorial deficits were excluded from both the groups.

For registration of jaw movements, we used the electrognathography (Bio-Research ${ }^{\circledR}$ Associates and the BioPak Program ${ }^{\mathrm{TM}}$ software), with a notebook computer. In the exams, the participant was instructed to remain seated in a chair and then a magnetic sensor (magnet) was fixed in the oral mucosa, below the lower central incisors, with Corega ${ }^{\circledR}$ tape. Soon after, the electrognathography was attached to the participant's head, and adjustments were made to position the equipment in relation to the anatomical features of the child (Figure 1).

Then a printed picture of figures of easy appointment ${ }^{(14,15)}$ was presented, containing all phonemes of Portuguese. The participant was asked to appoint, in sequence, all figures, to capture the jaw movements during speech (Figure 2). The route of the

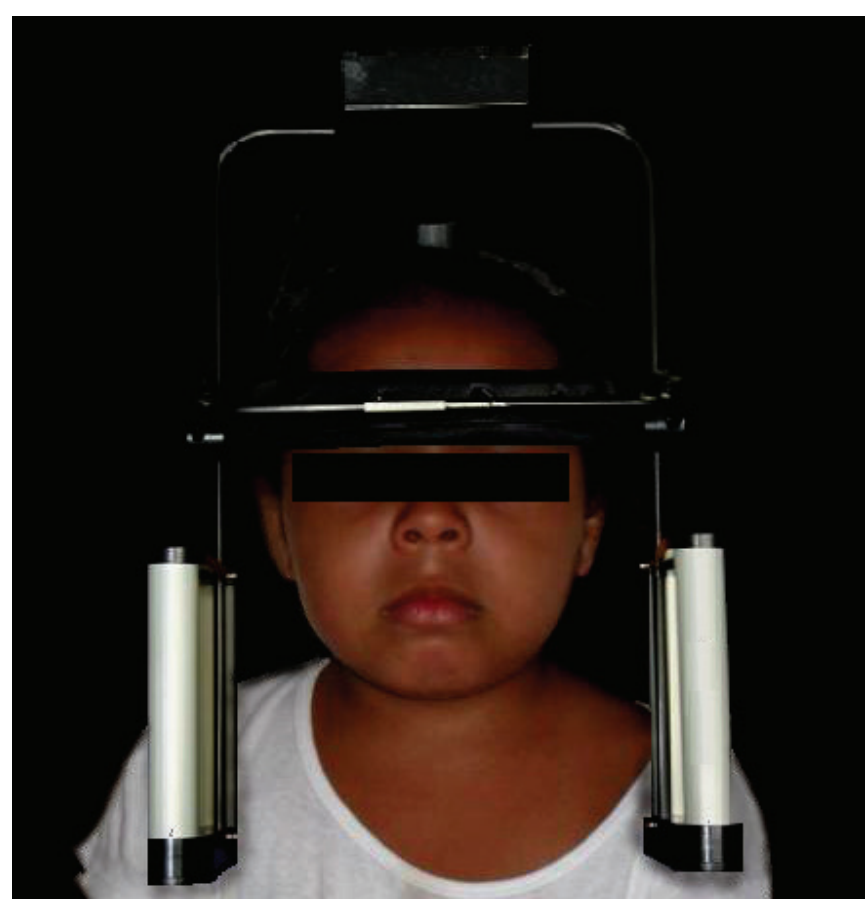

Figure 1. Electrognathography positioned on the child's head 
jaw during the appointment of figures was recorded using the software for further data analysis (Figure 3).

For descriptive statistical analysis, we considered the mean, standard deviation, and the confidence interval. For comparison between case and control groups, the Mann-Whitney nonparametric test was adopted; to verify the correlation between the
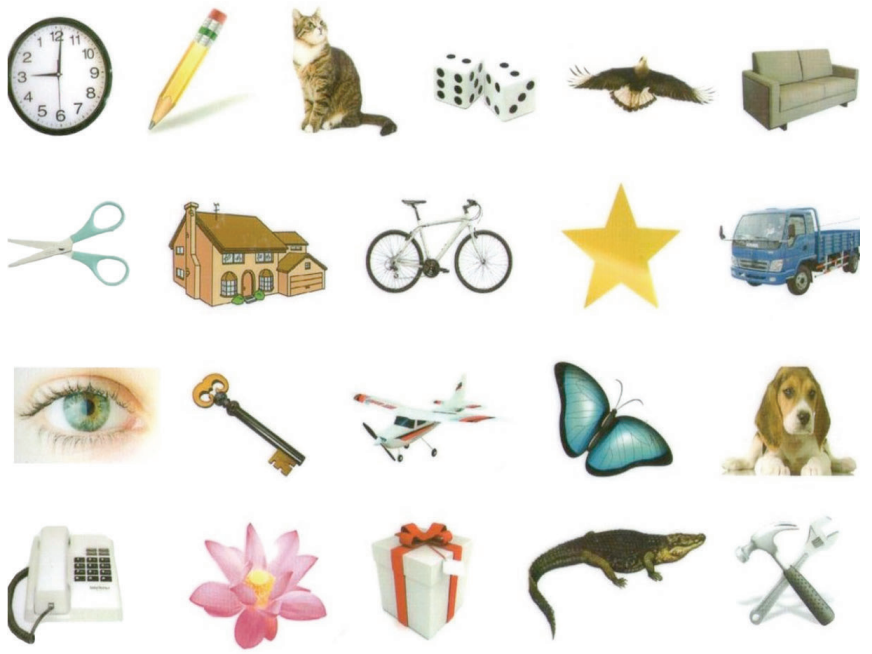

Figure 2. Frame with phonetically balanced figures for Brazilian Portuguese amplitude of jaw opening and the velocity during opening and closing of the mouth, the Spearman correlation test was used (significance level was 95\%).

Data collection was initiated after approval of the research ethics committee of the institution (CAAE: 10733513.4.0000.5208; opinion no 257 940), and parents signed an informed consent before the proceedings were initiated.

\section{RESULTS}

The sample comprised $56.25 \%$ of female children and $43.75 \%$ male, showing a homogeneous inclusion of participants. In addition, the rhinitis group had half the participants belonging to each of the sexes, whereas the control group was composed of $62.5 \%$ female.

Table 1 shows a higher mean of amplitude of jaw opening in the control group, with a $2.23 \mathrm{~mm}$ difference compared to the case group, but with no statistical significance. In addition, in the data related to jaw opening velocity, in both groups, a difference of $10.31 \mathrm{~mm} / \mathrm{s}$ is observed between the means, and the speed of this movement is larger in the control group; however, no statistically significant difference was observed between these results. A difference of $12.31 \mathrm{~mm} / \mathrm{s}$ was also observed between the means of case and control groups in the variable jaw closing velocity, and the control group had a faster closing, although it was not a significant difference. From the confidence interval calculation, a lower dispersion was evidenced

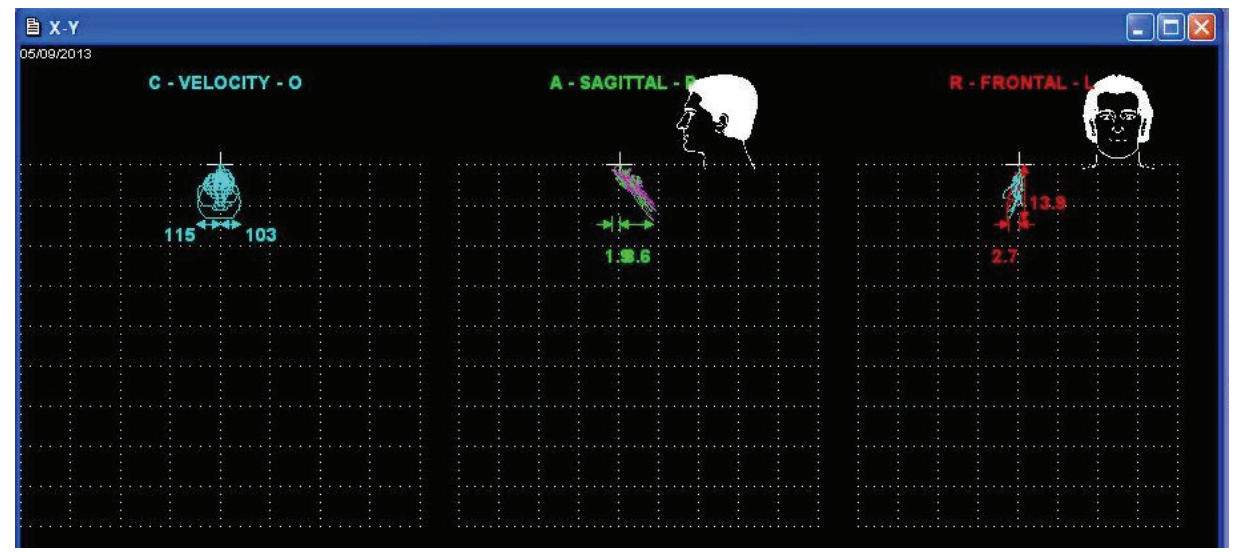

Figure 3. Record of the velocity (blue) and jaw movements during speech in the frontal (red) and sagittal (green) in a volunteer

Table 1. Comparison between the amplitude of jaw opening and jaw opening and closing velocity in millimeters during speech in volunteers of case and control groups

\begin{tabular}{|c|c|c|c|c|c|c|c|c|c|}
\hline \multirow{2}{*}{ Variable } & \multicolumn{4}{|c|}{ Case $(n=16)$} & \multicolumn{4}{|c|}{ Control $(n=16)$} & \multirow{2}{*}{$\mathrm{p}$-value } \\
\hline & Mean \pm SD & $\mathrm{Cl}$ & Median & Median & Mean \pm SD & $\mathrm{Cl}$ & Min.-Max. & Median & \\
\hline Amplitude & $13.18 \pm 4.09$ & $11.00-15.37$ & 16.5 & 16.5 & $15.75 \pm 6.32$ & $12.38-19.12$ & $5.60-26.10$ & 18 & 0.175 \\
\hline $\begin{array}{l}\text { Opening } \\
\text { velocity }\end{array}$ & $78.00 \pm 28.18$ & 62.98-93.02 & 97.5 & 97.5 & $88.31 \pm 52.20$ & $60.49-116.13$ & 10-200 & 111 & 0.650 \\
\hline $\begin{array}{l}\text { Closing } \\
\text { velocity }\end{array}$ & $89.94 \pm 40.76$ & $68.21-111.66$ & 104.5 & 104.5 & $102.25 \pm 52.71$ & $74.16-130.34$ & $26-227$ & 132 & 0.462 \\
\hline
\end{tabular}

Mann-Whitney nonparametric test $-\mathrm{p}<0.05$

Caption: SD = standard deviation; SD = standard deviation; $\mathrm{Cl}=$ confidence interval (95\%); Min = minimum; Max. = maximum 
in the case group, which points to a more accurate estimate of the value of individuals with allergic rhinitis. These values indicate that there are no differences between the control group and the group with allergic rhinitis, considering the variables of the mandibular movements studied: jaw opening amplitude, jaw opening velocity, and jaw closing velocity during speech.

Table 2 shows a positive correlation between amplitude and jaw opening velocity, and this was slightly higher in the case group, whereas the correlation between amplitude and jaw closing velocity was positive and strong in both groups. Considering these findings, it is possible to note that the numerical values of the amplitude and jaw opening and jaw closing velocity are directly proportional. Such analyses of the Spearman correlation coefficient were made considering the distance of the actual values of the perfect coefficient of reference, represented by the number one.

Table 2. Correlation between the amplitude of jaw movements and jaw opening and closing velocity during speech in volunteers of case and control groups

\begin{tabular}{lccllc}
\hline & \multicolumn{2}{c}{ Opening velocity } & & \multicolumn{2}{c}{ Closing velocity } \\
\cline { 2 - 3 } \cline { 5 - 6 } & rho & p-value & & rho & p-value \\
\hline Amplitude & & & & \\
$\quad$ Control Group & 0.591 & 0.016 & & 0.665 & 0.005 \\
Case Group & 0.712 & 0.002 & & 0.776 & $<0.001$ \\
\hline
\end{tabular}

$p<0.05$

Caption: rho = correlation coefficient of Spearman's rank

\section{DISCUSSION}

Analysis of the mandibular dynamics is pointed in some studies as an important mean of evaluation of the functional state of the stomatognathic system, as well as an auxiliary tool for the correct diagnosis of possible alterations ${ }^{(16,17)}$. It is observed in the literature that the research conducted to verify the jaw movement presents a variety of clinical situations studied, which also shows the reliability of electrognathography in obtaining clinical data on the speed and scale of these movements ${ }^{(12)}$.

Although no statistically significant differences were observed between the measurements of mandibular movement in children with and without rhinitis, some considerations are possible.

Initially considering the data related to the distribution of sexes in the groups studied, there was a homogeneous allocation of participants. Therefore, in a study with the objective of evaluating the mandibular movements of children through the use of the caliper, no differences were found in the jaw opening amplitude in the comparison between male and female, supporting the findings of this study ${ }^{(18)}$.

In relation to the data of the amplitude of jaw opening, the result of a quantitative characterization study of mandibular movements showed a value of $12.77 \mathrm{~mm}$ in the sagittal plane during speech ${ }^{(17)}$. This is similar to the findings of this research, considering the ratings of standard deviation, both in control and in the case group, although the study focused on adults.

Another study of adults using a similar electromagnetic analysis showed an average opening of the mouth of $14.5 \mathrm{~mm}$ during speech, which suggests, in addition to discrete values for this variable, small differences between asymptomatic children and young adults ${ }^{(19)}$. In this regard, the literature showed, in studies of measurement of mandibular movements through the caliper, that the maximum amplitude of mouth increases according to the age ${ }^{(20,21)}$. However, we can infer by these findings that possibly a little broad nature of these movements and the few changes seen in the comparison between age groups would be associated to the complex nature of motor control during speech. The amplitude of jaw movement in this function does not have to be proportional to the maximum opening of the mouth.

Furthermore, other studies showed lower values than the above, ranging from 2 to $8.6 \mathrm{~mm}^{(22-24)}$. One possible explanation for the cause of this discrepancy would be associated with the language, which highlights the importance of studies that characterize the mandibular movements in Portuguese ${ }^{(25)}$.

The resulting data show differences, but not statistically significant, in the values observed among the investigated groups; however, such changes may indicate that possible orofacial alterations in the stomatognathic system, present in the rhinitis group, justify such findings.

The data show high values of velocity during the opening and closing of jaw in speech, both in the control and in the case group, with a higher speed during closing. Considering this, in one study ${ }^{(17)}$ with asymptomatic adults, velocities of 88.65 and $89.90 \mathrm{~mm} / \mathrm{s}$ were observed during the opening and closing movements of the jaw, respectively, which shows a small increase in the mouth closing speed. It can be inferred from these results that this speed increase in mandibular closure is related to masticatory function, as it depends on an integrated complex of muscles that raise and lower the jaw, and the efficiency of this function is directly related to the contraction force of these muscles, especially the jaw elevators ${ }^{(26)}$.

Also in relation to the velocity of the mandibular movement, it can be noted, from the means, that the values for both opening and closing of jaw were lower in the group with rhinitis. According to Murdoch ${ }^{(27)}$, the jaw velocity depends, among other factors, on the action of the muscles and ligaments of the stomatognathic system. Considering this, it is noted that the literature indicates a large prevalence of oral breathing in subjects with allergic rhinitis, and neuromuscular changes in the stomatognathic system found in the mouth breathing that cause hypofunction and muscular hypotonia, especially in the jaw elevator muscle ${ }^{(28,29)}$. Thus, it is possible that the decrease in jaw velocity in the group of children with allergic rhinitis is related to alterations in the respiratory mode caused by nasal obstruction.

Regarding the comparison between the amplitude and the jaw opening and closing velocities, a study ${ }^{(17)}$ also mentioned 
that there is a direct relationship between these variables. In this study, a statistically significant positive correlation was observed in both groups, which is slightly higher in children with rhinitis. Although this difference is small, we can infer that this result is related to the fact that the numerical values of the control group are more heterogeneous, possibly by the existence of physiological conditions of the stomatognathic system not addressed in the exclusion criteria and that can modify muscle condition, such as facial type. One fact that can strengthen this conjecture are the values of the confidence interval of the index, which presented less dispersion in the group of children with rhinitis and higher in the control group in all analyses, showing greater range of values in the latter group, considering the minimum and maximum values in millimeters.

In addition, one might think, with these data, that possibly the correlation between the opening amplitude variables and the opening and closing jaw velocities increases in the occurrence of discrete values in these variables, which was observed in the group with allergic rhinitis. The findings may also be related to some limiting factors of the research, such as the usage of a nonprobabilistic sample and a small number of participants, in addition to no prior evaluation of stomatognathic changes of the patients, which would be relevant in future studies involving allergic rhinitis. We also suggest, in future studies, an investigation of the presence of signs and symptoms of temporomandibular dysfunction, considering evidence that show possible alterations in jaw movements in speech under that condition.

\section{CONCLUSION}

The results showed no significant statistical difference between the jaw movements in the presence and absence of allergic rhinitis, considering the variables studied, showing that the amplitude of jaw opening and the velocity of mandibular movements during speech have similar values among children with and without allergic rhinitis. Nevertheless, significant correlation was found between these variables of the jaw movement, with a greater level of correlation in the group of children with allergic rhinitis.

It was also observed that children without allergic rhinitis had greater heterogeneity in the values of variables than the ones with allergic rhinitis.

These results may indicate the intimate relationship between the mandibular dynamics and the balance of the stomatognathic system, and provide additional information to clinical practice on orofacial functional changes secondary to allergic rhinitis.

*SJHL participated in data collection, analysis of collected data, statistical calculations, and writing of the article; LAP participated in the implementation of the statistical calculations and revision of the article; $A L L$ participated in data collection and revision of the article; LCAA participated in the analysis of statistical calculations; HJS was responsible for scientific guidance and participated in the revision and writing of the article.

\section{REFERENCES}

1. Ibiapina CC, Sarinho ESC, Camargos PAM, Andrade CR, Cruz Filho AAS Rinite alérgica: aspectos epidemiológicos, diagnósticos e terapêuticos. J Bras Pneumol. 2008;34(4):230-40.

2. Weckx LL, Lopes CP, Naspitz N, Naspitz CK. Apostila do respirador bucal. São Paulo: Unifesp; 2001. p. 1-24.

3. Lemos CM, Wilbelmsen NSW, Mion OG, Mello-Júnior JF. Alterações funcionais do sistema estomatognático em pacientes com rinite alérgica: estudo caso-controle. Braz J Otorhinolaryngol. 2009;75(2):268-74.

4. Luzzi V, Lerardo G, Viscogliosi A, Fabbrizi M, Consoli G, Vozza I, et al. Allergic rhinitis as a possible Rick factor for malocclusion: a case-control study in children. Int J Paediatr Dent. 2013;23(4):274-8.

5. Campanha SMA, Fontes MFJ, Camargos PAM, Freire LMS. The impact of speech therapy on asthma and allergic rhinitis control in mouth breathing children and adolescents. J Pediatr (Rio J). 2010;86(3):202-8.

6. Wandalsen GF, Mendes AI, Solé D. Correlação entre resistência nasal e diferentes parâmetros da rinometria acústica em crianças e adolescentes com e sem rinite alérgica. Braz J Otorhinolaryngol. 2012;78(6):81-6.

7. Cunha DA, Silva GAP, Silva HJ. Repercussões da respiração oral no estado nutricional: por que acontece? Arquivos Int Otorrinolaringol. 2011;15(2):223-30.

8. Köhler GI, Köhler JFW. A importância do enfoque terapêutico multidisciplinar nas inadequações morfofuncionais da face. Ortodont Paranaen. 1992;13(1):17-39.

9. Marchesan IQ, Krakauer. A importância do trabalho respiratório na terapia miofuncional. In: Marchesan IQ, Bolaffi C, Gomes ICD, Zorzi JL. Tópicos em Fonoaudiologia. São Paulo: Lovise; 1995. p. 15-60.

10. Camargo MEPS, Respiração: movimento de vida. Rev Temas Sobre Desenvolv. 2004;13(77):27-36.

11. Nishimura CM, Gimenez SRML. Perfil da fala do respirador oral. Rev CEFAC. 2010;12(3):505-8.

12. Pinheiro PF Jr, Cunha DA, Filho MG, Caldas AS, Melo TM, Silva HJ The use of electrognathography in jaw movement research: a literature review. Cranio. 2012; 30(4): 293-303.

13. Wertzner HF, Silva LM. Velocidade de fala em crianças com e sem transtorno fonológico. Pró-fono. 2009;21:19-24.

14. Marchesan IQ. Avaliação e terapia dos problemas da respiração. In: Marchesan IQ. Fundamentos em Fonoaudiologia: aspectos clínicos da motricidade oral. Rio de Janeiro: Guanabara Koogan; 1998. p. 23-36.

15. Bianchini EMG, Andrade CF. A model of mandibular movements during speech: normative pilot study for the Brazilian Portuguese Language. Cranio. 2006;24(3):197-206.

16. Okeson JP. História e exame das desordens têmporomandibulares. In: Okeson JP. Tratamento das desordens temporomandibulares e oclusão. $6^{\text {a }}$ ed. São Paulo: Elsevier Editora Ltda.; 2008. p. 173-28.

17. Anelli W. Atuação fonoaudiológica na desordem temporomandibular. In: Lopes FOC. Tratado de fonoaudiologia. São Paulo: Editora Roca; 1997. p. 821-8.

18. Hamazaki CM, Kawaura R, Bianchini EMG, Assencio-Ferreira VJ Verificação da amplitude dos movimentos mandibulares em crianças. Rev CEFAC. 2002;4(1):35-40.

19. Nielsen IL, Marcel T, Chun D, Miller AJ. Patterns of mandibular movements in subjects with craniomandibular disorders. J Prosthet Dent.1990; 63(2): 202-17.

20. Machado BCZ, Medeiros APM, Felício CM. Limite de movimentos mandibulares em crianças. Pró-fono. 2009;21(3):189-94.

21. Leles CR, Neto JJSM, Giro EMA, Compagnoni MA. Valores normais da amplitude do movimento mandibular em crianças. Pós-Grad Rev Fac Odontol. 2000;3(2):121-6.

22. Peraine M, Salsench J, Torrent J, Noqueras J, Samso J. Study of mandibular movements during speech. Cranio. 1990;8(4):324-31.

23. Howell PG. Incisal relationships during speech. J Prosthet Dent.1986;56(1):93-9. 
24. Burnett CA. Reproducibility of the speech envelope and interocclusal dimensions in dentate subjects. Int J Prosthodont. 1994;7(6):543-8.

25. Bianchini EMG, Paiva G, Andrade CRF. Mandibular patterns during speech in subjects with temporomandibular disorders and in asyntomatic individuals. Cranio. 2008;26(1):50-8.

26. Nascimento GKBO. Eletromiografia de superfície do músculo masseter durante a mastigação: Uma revisão sistemática. Rev CEFAC. 2012;14(4):725-31.
27. Murdoch BE. In: Murdoch BE. Desenvolvimento da fala e distúrbios da linguagem: uma abordagem neuroanatômica e neurofisiológica. Rio de Janeiro: Editora Revinter; 1997. p. 67-89.

28. Barros JRC, Becker HMG, Pinto JA. Evaluation of atopy among mouth breathing pediatric patients referred for treatment to a tertiary care center. J Pediatr (Rio J.). 2006;82(6): 458-64.

29. Abreu RR, Rocha RL, Lamounier JA, Guerra AFM. Etiologia, manifestações clínicas e alterações presentes nas crianças respiradoras orais. J Pediatr (Rio J.). 2008;84(6):529-35. 